\title{
Talking Trump: How the Trump Rally Effectively Secured Donald J. Trump the Presidency
}

Michael Brown 


\section{Review of the Literature}

\section{The Speaker: Donald J. Trump}

Born and raised in Queens in 1946, Donald Trump, is an American case study in and of himself. Trump lived an upper-middle class life growing up, first attending military prep school before going to Fordham College and finally ending up at Wharton Business School with a Bachelor of Science (B.S.) in Economics. His story from here is well-documented. Trump took his father's real-estate business to new heights by investing in and renovating properties in Manhattan, including The Plaza hotel. Trump's wealth and rugged "consider-it-done" mentality propelled him to national fame in the 1980s, despite his many failures, including investments in Atlantic City, Trump Airlines, and Trump University. "The Donald," however, continued to expand not only his wealth, but his brand image. Early on it became apparent that Trump was a much savvier marketer than real-estate mogul or businessman.

In 1987, Trump wrote his bestselling book The Art of the Deal, which stayed on the New York Times Best Seller list for 48 weeks. Later in 2002, Trump, along with Mark Burnett, created the famous NBC show “The Apprentice." Because of this show, Trump's catchphrase "You're fired!" became part of the American lexicon.

Politically, Trump has been all over the spectrum. He first registered as a Republican in 1987, switched to the independent "Reform Party" in 1999, the Democratic Party in 2001, and finally back to the Republican Party in 2009.

\section{Aristotle's Proofs and Rhetorical Devices}

One of the most basic tenets of Communication Studies is the understanding and implication of Aristotle's Rhetorical Proofs. As Keith and Lundberg (2008) point out in their book The Essential Guide to Rhetoric, logos (logical appeal), ethos (credibility appeal), and pathos (passion/emotional appeal) are the foundation of any persuasive address: "Proofs are the ways we can make speech persuasive" (Keith \& Lundberg, 2008, p. 29). Whether known or unknown to the speaker, Trump uses some form of these proofs as a means to reach his audience. Given the focus on rhetorical proofs, research also focused on the "rhetorical situation," which is again defined by Keith and Lundberg (2008) as "the context, time, audience, and circumstances that surround a speech" (p. 77).

Additionally, other rhetorical devices were constantly used by Trump and evaluated by the researcher. Perhaps most significant in Trump's case is the fallacy of the "ad hominem attack." This is defined by Keith and Lundberg (2008) as "instead of focusing on the argument, the speaker makes judgements or personal attacks about the person advancing the opposite side of the argument" (p. 48). Trump is notorious for his ad hominem attacks in the form of nicknames such as "Crooked Hillary" or "Lying Ted."

Trump's use of ad hominem attacks and other fallacies has faced questioning, often focused on his effectiveness. One of the foremost questioners is Orly Kayam. In her piece “Donald Trump's Rhetoric” (2016), Kayam claims that Trump used typically anti-political devices such as "negativity, simplicity, repetition and hyperbole" to paint himself as an outsider. Kayam (2016) makes a point to say that Trump promotes the message of anti-intellectualism. This article takes a markedly pessimistic view of the President's then campaign, going as far as calling him a deceptive communicator. 


\section{Nonverbal communication}

Just as important as one's spoken language is one's use of body language to convey a message. Nonverbals can make or break a political candidate as Knapp, Hall, and Horgan (2014) point out in their work Nonverbal Communication in Human Interaction. With regard to political nonverbals, the researchers refer back to the 1960 Presidential debate where candidate John F. Kennedy put much more time into his appearance, posture, gesture, and tone than Richard Nixon. In one of the closest elections in history, many researchers like Knapp, Hall, and Horgan (2014) argue that Nixon's sweaty upper lip may have cost him the White House.

Trump knows the importance of image. From his very first speech where he descended from the escalator in Trump Tower, candidate Trump has constantly altered his environment and his body to appeal to his audience. His gestures, using emblems and his frequent repetition, make him a daunting candidate to study from a nonverbal perspective (Knapp, Hall, Horgan, 2014).

Trump's deliberate use of nonverbal communication illustrates that he does give a substantial amount of thought to the field of communication performance. In fact, in his 2004 book How to get Rich Trump dedicates two chapters of the book to "The Art of Public Speaking." In one instance, the American billionaire describes how much he enjoys rhetoric: "I know some people dread the thought of having to give a presentation.... Not me. I get so much energy from audiences that it's always fun" (61). Trump is a natural performer. The man does not shy away from the spotlight. While he may not be the most eloquent speaker, his performances are "must-see-TV." Trump gives perhaps his most important tool to understand his delivery: "Think about your audience first. The rest will fall into place. . . Involve your audience. They will appreciate being included" (64).

At the conclusion of his two chapters on public address, Trump gives the reader 11 points to consider:

1. Think about your audience first.

2. Get your audience involved.

3. Be prepared.

4. Be a good storyteller.

5. Be aware of the common denominator.

6. Be an entertainer.

7. Be able to laugh at yourself.

8. Think on your feet.

9. Listen.

10. Have a good time.

And, of course ....

11. Study Regis Philbin (68).

Trump utilizes tenets 1, 2, 4, 6, and 10 in his campaign speeches. Trump frequently refers to Regis Philbin, host of daytime talk show Live with Regis $\mathcal{E}$ Kathie Lee, as an inspiration for his demeanor and speaking style. 


\section{Method}

In answering if Trump's rhetoric played a vital role in securing his presidency, I set certain strict guidelines to ensure that the research could be manageable. The method for this data collection focused on three aspects of rhetorical analysis within seven of Trump's speeches. This section will outline why the speeches were chosen and the three aspects of rhetorical data examined in each.

Because Trump has given an overwhelming number of speeches, a substantial part of the methodological process was narrowing down sources in order to get meaningful qualitative data. The first constraint to delimit the study was establishing that this thesis would focus only on President Trump's rhetorical performances between his announcement on June 15, 2015 and his victory on November 8, 2016. In keeping with the spirit of communication studies, the goal is to focus only on the spoken word. This means that, despite their probable effectiveness in swaying voters, candidate Trump's social media tweets were not analyzed. Looking at Trump's speaking engagements, it became apparent that his rallies were the most well-attended and electric of all his public addresses. With that in mind, the focus of this study remained mostly on "Trump Rallies.” This means that Trump's performances in debates with other Republicans and/or (potential) Democratic nominee Secretary Clinton, no matter how effective they may have been, were not analyzed.

\section{Speech Selection}

The following list contains seven of Trump's speeches, along with a brief rationale for why each speech was chosen to analyze. A common theme with each rally is location and timing. The question, "Why did Trump and his campaign choose to speak here at this time?" was considered throughout the analysis.

1. June 15, 2015, New York, NY-Campaign Announcement Speech

Rationale: This speech from the Trump Tower in New York City, NY lays the framework for Trump's campaign. However, it is more of an outlier than the other speeches. It is scripted at times and there is not a lot of audience engagement. This speech marks the first time Trump attacks the media.

2. March 12, 2016, Cleveland, OH-Campaign Rally

Rationale: One of the first Trump speeches to have his trademark rally-like atmosphere, this is the largest crowd at a primary event with 20,000 people.

3. June 07, 2016, New York, NY-Remarks after Winning Primaries in Montana, South Dakota, New Mexico, New Jersey and California

Rationale: This is Trump's first speech after becoming the presumptive Republican nominee. Trump visited the areas where he would struggle in the general election, western states.

4. July 21, 2016, Cleveland, OH-Address Accepting the Presidential Nomination at the Republican National Convention

Rationale: A small outlier amongst Trump speeches, it has more of a scripted and traditional feel. This speech was very different when compared to the speech in Cleveland four months earlier. 
5. August 19, 2016, Dimondale, MI-Remarks at the Summit Sports and Ice Complex

Rationale: Here, the geographic location is an interesting one, with a population of only 60,000 . Dimondale is one of the smallest towns Trump held a rally in; the closest major town is Lansing, an hour and a half drive away.

6. November 01, 2016, Valley Forge, PA-Remarks on Obamacare

Rationale: This speech occurred the week of the general election in a crucial swing state. Here, Trump only speaks on Health Care issues, particularly Obamacare. This speech was part of Trump's famous "PA Push" to flip the state. Ironically, this speech would feature an ill/low energy candidate Trump.

7. November 07, 2016, Raleigh, NC-Remarks at J.S Dorton Arena

Rationale: This was Trump's final speech before the primary election, held in a state Trump won by a very narrow margin.

\section{Data Collection}

A crucial aspect of method collection was determining what type of rhetorical data to collect from these speeches. Obviously, quantitative data would be extremely difficult to collect given that many of these speeches are longer than an hour in length. Therefore, three aspects of communication studies, which are deemed crucial to effective communication, were identified as the focus: 1) Aristotle's proofs 2) Nonverbal communication and 3) Frequency/repetition.

\section{Aristotle's Proof's and Rhetorical Devices}

First, I conducted a search for rhetorical elements. The foundation of communication studies relies on Aristotle's proofs: logos, ethos, and pathos. In many ways, Trump's communication challenged traditional notions of "effective communication" that rely on these three core tenets. Through conducting rhetorical analysis on Winston Churchill's speeches in the 1940s, I gained prior knowledge on traditional and presidential rhetorical elements. On the first pass through Trump's speeches, observations focused heavily on the elements of the rhetorical situation. Whenever a moment which held significant rhetorical weight was observed, the time and line were marked in a document and analysis was also added.

\section{Nonverbal Communication}

Next, research focused on the nonverbal component of candidate Trump's speeches. Nonverbal communication offers important aspects of effective communication, and Trump is known and often parodied for his frequent and over-the-top nonverbal gestures. To analyze Trump's nonverbal communication, I watched all of the listed Trump speeches without sound, noting the type and frequency of the gesture. Within three speeches, a rhetorical analysis on candidate Trump's use of gestures and emblems was effectively conducted, as gestures were clear and consistent. A decision was then made to cease further analysis of the remaining four speeches due to the saturation of data by this point.

\section{Strategic Message Use}

Finally, the researcher looked for overall repetition, overlapping messages, and tone within Trump's speeches. To conduct this analysis, an Excel spreadsheet was utilized to note the frequency within individual speeches and also frequency of messages across the collection of the campaign. The types of messages 
were broken down into seven categories: 1) Immigration/The Wall, 2) Black America 3) Ad Hominem Attacks 4) Jobs 5) Trade 6) "Classic Conservativism" and 7) Make American Great Again (MAGA). The "Classic Conservativism" category refers to messages which had also been used during Presidents Ronald Reagan and Richard Nixon's campaign. Phrases such as "The silent majority," or "Government is the problem," would fall into this category (Whitney, 2004). As speeches were listened to for the third time, tally marks were kept for each speech in their respective categories when a message was heard. This pass marked more than 14 hours of listening to candidate Donald Trump.

\section{Results}

The following section presents the data collected and contains the results of three passes through seven of Trump's addresses. In the first pass, I analyzed the use of rhetorical devices. In the second pass, nonverbal communication was analyzed. Finally, the third pass contains an Excel table to illustrate repetition. 


\section{First Pass - Rhetorical Devices}

\section{Speech \#1- Presidential Campaign Announcement 6/15/2015}

Trump Tower, New York, NY

\begin{tabular}{|c|c|c|}
\hline Time & Remark & Rhetorical Device \\
\hline $00: 17$ & $\begin{array}{l}\text { "ARE WE GOING TO WIN } \\
\text { OHIO?" }\end{array}$ & $\begin{array}{l}\text { Rhetorical Question. } \\
\text { Audience engagement. }\end{array}$ \\
\hline $00: 30$ & $\begin{array}{l}\text { "I wish they (points to media) } \\
\text { could be honest." }\end{array}$ & $\begin{array}{l}\text { Creates common enemy, } \\
\text { Pathos. }\end{array}$ \\
\hline $3: 30$ & "I love you. I love you too." & Pathos. \\
\hline $4: 45$ & $\begin{array}{l}\text { "All over the world they are } \\
\text { talking about the momentum } \\
\text { we have. They are calling it a } \\
\text { movement. Not me, they are } \\
\text { calling it that. A movement. } \\
\text { It's you, I'm just the } \\
\text { messenger." }\end{array}$ & Pathos. \\
\hline $5: 12$ & $\begin{array}{l}\text { "We are losing our jobs, and } \\
\text { our factories." }\end{array}$ & Logos. \\
\hline $5: 40$ & $\begin{array}{l}\text { "On the left (in this building) } \\
\text { we have Ford. Moving to } \\
\text { Mexico. And to the right, you } \\
\text { have Eaton. Moving to } \\
\text { Mexico..." }\end{array}$ & Logos. \\
\hline $6: 50-7: 55$ & $\begin{array}{l}\text { Another protestor. Trump } \\
\text { imitates Bernie for a second } \\
\text { time. He spends a whole min } \\
\text { make fun of protestor. }\end{array}$ & Ad Hominem. \\
\hline 8:50 & $\begin{array}{l}\text { "We are going to...We are } \\
\text { going to ...." }\end{array}$ & Repetition. \\
\hline $9: 54$ & $\begin{array}{l}\text { "Think about it, we have a 5- } \\
\text { billion-dollar trade deficit to } \\
\text { China, and every direction I } \\
\text { point to in this arena we are } \\
\text { losing plants to China. How } \\
\text { are we going to make that up? } \\
\text { It's not going to happen." }\end{array}$ & Logos. \\
\hline $10: 30$ & $\begin{array}{l}\text { "You've got a governor who } \\
\text { has abandoned his state. And } \\
\text { everywhere he's gone to } \\
\text { campaign. I've won." }\end{array}$ & Ethos. \\
\hline $11: 00$ & $\begin{array}{l}\text { "Did you know your } \\
\text { governor was a managing } \\
\text { director of Lehman Brothers? }\end{array}$ & Logos. \\
\hline
\end{tabular}




\begin{tabular}{|c|c|c|}
\hline & $\begin{array}{l}\text { It almost destroyed the world } \\
\text { in 2008." }\end{array}$ & \\
\hline $13: 03$ & $\begin{array}{l}\text { Another protestor. This time } \\
\text { Trump responds "Let's do a } \\
\text { U-S-A chant. USA!" }\end{array}$ & Pathos. \\
\hline $14: 02$ & $\begin{array}{l}\text { "Your gov is letting your } \\
\text { steel industry is going to } \\
\text { hell." }\end{array}$ & Ad hominem. Ethos. \\
\hline $16: 20$ & $\begin{array}{l}\text { "Little Marco has the worst } \\
\text { voting record in the Senate in } \\
\text { the last century, who THE } \\
\text { HELL wants him to represent } \\
\text { you?!" }\end{array}$ & Ad hominem. Logos. \\
\hline $22: 02$ & $\begin{array}{l}\text { "I have a store worth more } \\
\text { than Mitt Romney." }\end{array}$ & Logos. Humor. \\
\hline $25: 40-26: 05$ & $\begin{array}{l}\text { New Hampshire heroine } \\
\text { story. }\end{array}$ & Pathos. Narrative. \\
\hline $27: 14$ & $\begin{array}{l}\text { Ivanka story. "Daddy will } \\
\text { you act Presidential in the } \\
\text { debate?" IMPORTANT. } \\
\text { Trump comments on his own } \\
\text { rhetoric style. Admits he was } \\
\text { too harsh in previous debates. } \\
\text { However, concedes he won't } \\
\text { act presidential when } \\
\text { companies take advantage of } \\
\text { America }\end{array}$ & Pathos. Narrative. \\
\hline $28: 00-30: 02$ & $\begin{array}{l}\text { "I hope you make a lot of air } \\
\text { conditioning units but here's } \\
\text { the story, every unit you } \\
\text { make that crosses the border - } \\
\text { - and now we're going have a } \\
\text { real border remember that. } \\
\text { We're going to have a real } \\
\text { border. We are charging you } \\
35 \% \text { tax on that unit, and you } \\
\text { know what they're going to } \\
\text { say, they're going to call up } \\
\text { their lobbyist but the } \\
\text { lobbyists can't get to me } \\
\text { because I haven't taken any of } \\
\text { their money." }\end{array}$ & Logos. Narrative. \\
\hline $35: 03$ & First time voter story & Ethos. Narrative. \\
\hline $37: 52$ & $\begin{array}{l}\text { "So } \\
\text { here's the story. We're going } \\
\text { to win and we're going to win }\end{array}$ & Repetition. Humor. \\
\hline
\end{tabular}




\begin{tabular}{|l|l|l|}
\hline & everywhere. We're going to \\
knock the hell out of ISIS. & We're going to win with \\
trade. We're going to win & with trade. We're going to \\
win with health. We're going & to win at so many levels. \\
We're going to, win, win, & win. You're going to get so \\
tired of winning. You're & going to say, Mr. President, \\
please, we don't want to win & anymore. It's too much. And \\
I'm going to say, I'm sorry, & we're going to keep winning \\
because we're going to Make & America Great Again. I love \\
you. Thank you. Thank you. & Go and vote on Tuesday. \\
Thank you. Thank you." & \\
\hline
\end{tabular}

Speech \#2 Cleveland, Ohio Rally

$03 / 12 / 2016$

Three days before Trump loses Republican primary to John Kasich (46\% to $35 \%$ )

I-X Center

Attendance: roughly 20,000

\begin{tabular}{|l|l|l|}
\hline Time & Remark & Rhetorical Device \\
\hline $00: 17$ & "ARE WE GOING TO WIN & $\begin{array}{l}\text { Rhetorical Question. Audience } \\
\text { OHIO?" }\end{array}$ \\
\hline $00: 30$ & $\begin{array}{l}\text { "I wish they (points to media) } \\
\text { could be honest." }\end{array}$ & $\begin{array}{l}\text { Creates common enemy, } \\
\text { Pathos. }\end{array}$ \\
\hline $3: 30$ & "I love you. I love you too." & Pathos. \\
\hline $4: 45$ & $\begin{array}{l}\text { "All over the world they are } \\
\text { talking about the momentum } \\
\text { we have. They are calling it a } \\
\text { movement. Not me, they are } \\
\text { calling it that. A movement. It's } \\
\text { you, I'm just the messenger." }\end{array}$ & \\
\hline $5: 12$ & $\begin{array}{l}\text { "We are losing our jobs, and } \\
\text { our factories." }\end{array}$ & Logos. \\
\hline $5: 40$ & $\begin{array}{l}\text { "On the left (in this building) } \\
\text { we have Ford. Moving to } \\
\text { Mexico. And to the right, you } \\
\text { have Eaton. Moving to } \\
\text { Mexico..." }\end{array}$ & Logos. \\
\hline
\end{tabular}




\begin{tabular}{|c|c|c|}
\hline $6: 50-7: 55$ & $\begin{array}{l}\text { Another protestor. Trump } \\
\text { imitates Bernie for a second } \\
\text { time. He spends a whole min } \\
\text { make fun of protestor. }\end{array}$ & Ad Hominem. \\
\hline $8: 50$ & $\begin{array}{l}\text { "We are going to...We are } \\
\text { going to ...." }\end{array}$ & Repetition. \\
\hline $9: 54$ & $\begin{array}{l}\text { "Think about it, we have a 5- } \\
\text { billion-dollar trade deficit to } \\
\text { China, and every direction I } \\
\text { point to in this arena we are } \\
\text { losing plants to China. How are } \\
\text { we going to make that up? It's } \\
\text { not going to happen." }\end{array}$ & Logos. \\
\hline $10: 30$ & $\begin{array}{l}\text { "You've got a governor who } \\
\text { has abandoned his state. And } \\
\text { everywhere he's gone to } \\
\text { campaign, I've won." }\end{array}$ & Ethos. \\
\hline $11: 00$ & $\begin{array}{l}\text { "Did you know your governor } \\
\text { was a managing director of } \\
\text { Lehman Brothers? It almost } \\
\text { destroyed the world in } 2008 .\end{array}$ & Logos. \\
\hline 13:03 & $\begin{array}{l}\text { Another protestor. This time } \\
\text { Trump responds "Let's do a U- } \\
\text { S-A chant. USA!" }\end{array}$ & Pathos. \\
\hline $14: 02$ & $\begin{array}{l}\text { "Your gov is letting your steel } \\
\text { industry is going to hell." }\end{array}$ & Ad hominem. Ethos. \\
\hline $16: 20$ & $\begin{array}{l}\text { "Little Marco has the worst } \\
\text { voting record in the Senate in } \\
\text { the last century, who THE } \\
\text { HELL wants him to represent } \\
\text { you?!" }\end{array}$ & Ad hominem. Logos. \\
\hline $22: 02$ & $\begin{array}{l}\text { "I have a store worth more than } \\
\text { Mitt Romney." }\end{array}$ & Logos. Humor. \\
\hline 25:40-26:05 & New Hampshire heroine story. & Pathos. Narrative. \\
\hline $27: 14$ & $\begin{array}{l}\text { Ivanka story. "Daddy will you } \\
\text { act Presidential in the debate?" } \\
\text { IMPORTANT. Trump } \\
\text { comments on his own rhetoric } \\
\text { style. Admits he was too harsh } \\
\text { in previous debates. However, } \\
\text { concedes he won't act } \\
\text { presidential when companies } \\
\text { take advantage of America } \\
\end{array}$ & Pathos. Narrative. \\
\hline 28:00-30:02 & $\begin{array}{l}\text { "I hope you make a lot of air } \\
\text { conditioning units but here's the } \\
\text { story, every unit you make that }\end{array}$ & Logos. Narrative. \\
\hline
\end{tabular}




\begin{tabular}{|c|c|c|}
\hline & $\begin{array}{l}\text { crosses the border -- and now } \\
\text { we're going have a real border } \\
\text { remember that. We're going to } \\
\text { have a real border. We are } \\
\text { charging you } 35 \% \text { tax on that } \\
\text { unit, and you know what they're } \\
\text { going to say, they're going to } \\
\text { call up their lobbyist but the } \\
\text { lobbyists can't get to me } \\
\text { because I haven't taken any of } \\
\text { their money." }\end{array}$ & \\
\hline $35: 03$ & First time voter story & Ethos. Narrative. \\
\hline $37: 52$ & $\begin{array}{l}\text { "So here's the story. We're } \\
\text { going to win and we're going to } \\
\text { win everywhere. We're going to } \\
\text { knock the hell out of ISIS. } \\
\text { We're going to win with trade. } \\
\text { We're going to win with trade. } \\
\text { We're going to win with health. } \\
\text { We're going to win at so many } \\
\text { levels. We're going to, win, } \\
\text { win, win. You're going to get so } \\
\text { tired of winning. You're going } \\
\text { to say, Mr. President, please, } \\
\text { we don't want to win anymore. } \\
\text { It's too much. And I'm going to } \\
\text { say, I'm sorry, we're going to } \\
\text { keep winning because we're } \\
\text { going to Make America Great } \\
\text { Again. I love you. Thank you. } \\
\text { Thank you. Go and vote on } \\
\text { Tuesday. Thank you. Thank } \\
\text { you." }\end{array}$ & Repetition. Humor. \\
\hline
\end{tabular}

Speech \# 3- Remarks after winning Primaries in Montana, South Dakota, New Mexico, New Jersey and California (Nomination secured.)

06/07/ 2016

Trump National Golf Club, Westchester, New York Attendance: 500 people

\begin{tabular}{|l|l|l|}
\hline Time & Remark & Rhetorical Device \\
\hline $1: 27$ & $\begin{array}{l}\text { "You know what this means? } \\
\text { We are only getting started } \\
\text { and it's gonna be beautiful." }\end{array}$ & Rhetorical Question. \\
\hline $1: 45$ & $\begin{array}{l}\text { It becomes obvious Trump is } \\
\text { reading off a scripted } \\
\text { teleprompter for this smaller }\end{array}$ & Speech prep. \\
\hline
\end{tabular}




\begin{tabular}{|c|c|c|}
\hline & $\begin{array}{l}\text { crowd. However, after each } \\
\text { sentence in the speech Trump } \\
\text { adds his own comments. } \\
\text { Great example here. }\end{array}$ & \\
\hline $2: 27$ & $\begin{array}{l}\text { "I will never never } \\
\text { ever ever let you down." }\end{array}$ & Repetition. \\
\hline $4: 10$ & $\begin{array}{l}\text { "And by the way, the terrible } \\
\text { trade deals that Bernie was so } \\
\text { vehemently against and he's } \\
\text { right on that will be taken } \\
\text { care of far better than anyone } \\
\text { ever thought possible and } \\
\text { that's what I do. We are going } \\
\text { to have fantastic trade deals. } \\
\text { We're going to start making } \\
\text { money and bringing in jobs." }\end{array}$ & Ethos. \\
\hline $4: 31$ & $\begin{array}{l}\text { "I built an extraordinary } \\
\text { business on relationships and } \\
\text { deals that benefit all parties } \\
\text { involved, always. My goal is } \\
\text { always again to bring people } \\
\text { together." }\end{array}$ & Ethos. \\
\hline $4: 45$ & $\begin{array}{l}\text { "I 'm going to be your } \\
\text { champion. I'm going to be } \\
\text { America's champion because } \\
\text { you see this election isn't } \\
\text { about Republican or } \\
\text { Democrat; it's about who runs } \\
\text { this country - the special } \\
\text { interests or the people and I } \\
\text { mean the American people." }\end{array}$ & Pathos. \\
\hline $6: 30$ & $\begin{array}{l}\text { "landslides all over the } \\
\text { country with every } \\
\text { demographic on track to win; } \\
37 \text { primary caucus victories } \\
\text { in a field that began with } 17 \\
\text { very talented people." }\end{array}$ & Logos. \\
\hline $7: 12$ & $\begin{array}{l}\text { "The Clintons have turned the } \\
\text { politics of personal } \\
\text { enrichment into an art form } \\
\text { for themselves. They've made } \\
\text { hundreds of millions of } \\
\text { dollars selling access, selling } \\
\text { favors, selling government } \\
\text { contracts, and I mean } \\
\text { hundreds of millions of }\end{array}$ & Ad hominem. \\
\hline
\end{tabular}




\begin{tabular}{|l|l|l|}
\hline & $\begin{array}{l}\text { dollars. Secretary Clinton } \\
\text { even did all of the work on a } \\
\text { totally illegal private server. } \\
\text { Something about how she's } \\
\text { getting away with this } \\
\text { folk nobody understands." }\end{array}$ & \\
\hline $9: 09$ & $\begin{array}{l}\text { "I did not have to do this...but } \\
\text { I felt I needed to give back to } \\
\text { this country." }\end{array}$ & Ethos. \\
\hline $16: 20$ & $\begin{array}{l}\text { "We are gonna take care of } \\
\text { our African American people } \\
\text { who have been mistreated for } \\
\text { so long." }\end{array}$ & Pathos. \\
\hline
\end{tabular}

Speech \#4- Trump's Acceptance of the Nomination- Cleveland, Ohio

\begin{tabular}{|c|c|c|}
\hline Time & Remark & Rhetorical Device \\
\hline $1: 33$ & Leads crowd in "U-S-A" & Pathos. \\
\hline $1: 54$ & $\begin{array}{l}\text { "We and I say WE, because } \\
\text { we are a team." }\end{array}$ & Pathos. \\
\hline $2: 07$ & $\begin{array}{l}\text { " } 14 \text { million votes, the most in } \\
\text { the history of the Republican } \\
\text { party. And that the republican } \\
\text { party would receive } 60 \% \\
\text { more votes than eight years } \\
\text { ago. The Democrats on the } \\
\text { other hand received } 20 \% \text { less } \\
\text { votes than four years ago." }\end{array}$ & Logos. \\
\hline $5: 36$ & $\begin{array}{l}\text { "We cannot afford to be } \\
\text { politically correct anymore." }\end{array}$ & Logos. \\
\hline $6: 16$ & $\begin{array}{l}\text { "If you want lies, the } \\
\text { Democratic Convention is } \\
\text { next week. Here there will be } \\
\text { no lies." }\end{array}$ & Ad hominem. \\
\hline $7: 53$ & $\begin{array}{l}\text { "That's the largest increase } \\
\text { (in crime) in } 25 \text { years" }\end{array}$ & Logos. \\
\hline $9: 16$ & Sarah Rute story & Narrative. Pathos. \\
\hline $11: 18$ & $\begin{array}{l}\text { "Billions and billions and } \\
\text { billions." }\end{array}$ & Repetition. \\
\hline $12: 00-13: 48$ & $\begin{array}{l}\text { Trump lists foreign policy } \\
\text { failures and then asks who is } \\
\text { responsible }\end{array}$ & Logos. Rhetorical Q. \\
\hline $20: 33$ & $\begin{array}{l}\text { "She will keep a rigged } \\
\text { system in place." }\end{array}$ & Pathos. \\
\hline $20: 45$ & $\begin{array}{l}\text { "She is the puppet and they } \\
\text { (DNC) are pulling the } \\
\text { strings." }\end{array}$ & Metaphor. \\
\hline
\end{tabular}




\begin{tabular}{|c|c|c|}
\hline $21: 00$ & "Never, ever" & Humor. \\
\hline $22: 22$ & "I am your voice." & Metaphor. \\
\hline $25: 22$ & $\begin{array}{l}\text { "Corruption has reached a } \\
\text { level we"ve never ever seen } \\
\text { before." }\end{array}$ & \\
\hline $45: 29$ & $\begin{array}{l}\text { "These families have no } \\
\text { special interests to represent } \\
\text { them. There are no } \\
\text { demonstrators to protest on } \\
\text { their behalf. My opponent } \\
\text { will never meet with them, or } \\
\text { share in their pain. Instead, } \\
\text { my opponent wants Sanctuary } \\
\text { Cities. But where was } \\
\text { sanctuary for Kate Steinle? } \\
\text { Where was Sanctuary for the } \\
\text { children of Mary Ann, Sabine } \\
\text { and Jamiel? Where was } \\
\text { sanctuary for all the other } \\
\text { Americans who have been so } \\
\text { brutally murdered, and who } \\
\text { have suffered so horribly?" }\end{array}$ & Rhetorical Q. Narrative. \\
\hline $53: 09$ & $\begin{array}{l}\text { "I have made billions of } \\
\text { dollars in business making } \\
\text { deals - now I'm going to } \\
\text { make our country rich again." }\end{array}$ & Ethos. \\
\hline $59: 57$ & $\begin{array}{l}\text { "America is one of the } \\
\text { highest-taxed nations in the } \\
\text { world. Reducing taxes will } \\
\text { cause new companies and } \\
\text { new jobs to come roaring } \\
\text { back into our country. Then } \\
\text { we are going to deal with the } \\
\text { issue of regulation, one of the } \\
\text { greatest job-killers of them } \\
\text { all. Excessive regulation is } \\
\text { costing our country as much } \\
\text { as } \$ 2 \text { trillion a year, and we } \\
\text { will end it. We are going to } \\
\text { lift the restrictions on the } \\
\text { production of American } \\
\text { energy. This will produce } \\
\text { more than } \$ 20 \text { trillion in job } \\
\text { creating economic activity } \\
\text { over the next four decades." }\end{array}$ & Logos \\
\hline
\end{tabular}




\begin{tabular}{|l|l|l|}
\hline $1: 10-1: 12$ & $\begin{array}{l}\text { "My Dad, Fred Trump, was } \\
\text { the smartest and hardest } \\
\text { working man I ever knew. I } \\
\text { wonder sometimes what he'd } \\
\text { say if he were here to see this } \\
\text { tonight. } \\
\text { It's because of him that I } \\
\text { learned, from my youngest } \\
\text { age, to respect the dignity of } \\
\text { work and the dignity of } \\
\text { working people. He was a } \\
\text { guy most comfortable in the } \\
\text { company of bricklayers, } \\
\text { carpenters, and electricians } \\
\text { and I have a lot of that in me } \\
\text { also. Then there's my mother, } \\
\text { Mary. She was strong, but } \\
\text { also warm and fair-minded. } \\
\text { She was a truly great mother. } \\
\text { She was also one of the most } \\
\text { honest and charitable people I } \\
\text { have ever known, and a great } \\
\text { judge of character." }\end{array}$ & \\
\hline $1: 15$ & MAGA & \\
\hline
\end{tabular}

Speech \#5- Campaign Rally

Dimondale, Michigan

$(08 / 12 / 2016)$

14,000 estimated capacity

\begin{tabular}{|l|l|l|}
\hline Time & Remark & Rhetorical Device \\
\hline $2: 03$ & $\begin{array}{l}\text { "We are going to bring jobs } \\
\text { back to our country, and we } \\
\text { are going to bring jobs back } \\
\text { to Michigan." First line of the } \\
\text { speech is about job creation. }\end{array}$ & \\
\hline $2: 29$ & $\begin{array}{l}\text { "Remember this, a big, big } \\
\text { victory for the factory } \\
\text { worker. They haven't had } \\
\text { those victories for a long } \\
\text { time. A victory for every } \\
\text { citizen and for all of the } \\
\text { people whose voices have not } \\
\text { been heard for many, many } \\
\text { years. They're going to be } \\
\text { heard again." }\end{array}$ & Pathos. Reoccurring theme. \\
\hline
\end{tabular}




\begin{tabular}{|c|c|c|}
\hline $3: 03$ & $\begin{array}{l}\text { "It is going to be YOUR } \\
\text { victory." }\end{array}$ & Pathos. \\
\hline $9: 22$ & $\begin{array}{l}\text { "The inner cities of our } \\
\text { country have been run by the } \\
\text { Democratic party for more } \\
\text { than } 50 \text { years. Their policies } \\
\text { have produced only poverty, } \\
\text { joblessness, failing schools, } \\
\text { and broken homes. It's time to } \\
\text { hold democratic politicians } \\
\text { accountable for what they } \\
\text { have done to these } \\
\text { communities. At what point } \\
\text { do we say enough?" }\end{array}$ & Logos. Rhetorical Question. \\
\hline $9: 45$ & $\begin{array}{l}\text { "It is time to hold failed } \\
\text { leaders accountable for their } \\
\text { results, not just their empty } \\
\text { words over and over again. } \\
\text { Look at what the democratic } \\
\text { party has done to the city -- as } \\
\text { an example and there are } \\
\text { many others, -- of Detroit. } 40 \\
\text { percent of Detroit's residents, } \\
40 \text { percent, live in poverty. } \\
\text { Half of all Detroit residents } \\
\text { do not work, and cannot } \\
\text { work, and can't get a job. } \\
\text { Detroit tops the list of the } \\
\text { most dangerous cities. } \\
\text { Number } 1 \text {. This is the legacy } \\
\text { of the Democratic leaders } \\
\text { who have run this city. } \\
\text { Crooked Hillary." }\end{array}$ & Logos. Pathos. Ad Hominem. \\
\hline $12: 02$ & $\begin{array}{l}\text { "To those people (African } \\
\text { American) I say "what do you } \\
\text { have to lose by trying } \\
\text { someone new? }\end{array}$ & Rhetorical question. Logos. \\
\hline $16: 03$ & $\begin{array}{l}\text { America must reject the } \\
\text { bigotry of Hillary Clinton, } \\
\text { who sees communities of } \\
\text { color only as votes, not as } \\
\text { human beings worthy of a } \\
\text { better future. Hillary Clinton } \\
\text { would rather provide a job to } \\
\text { a refugee from overseas, than } \\
\text { to give that job to }\end{array}$ & Pathos. \\
\hline
\end{tabular}




\begin{tabular}{|c|c|c|}
\hline & $\begin{array}{l}\text { unemployed African- } \\
\text { American youth in cities like } \\
\text { Detroit, who have become } \\
\text { refugees in their own } \\
\text { country." }\end{array}$ & \\
\hline $18: 22$ & $\begin{array}{l}\text { "We will invest a portion of } \\
\text { the money saved in the jobs } \\
\text { program for inner-city youth. } \\
\text { The African- } \\
\text { American community has } \\
\text { given so much to this } \\
\text { country. They fought and } \\
\text { died in every war since the } \\
\text { Revolution. They've lifted } \\
\text { up the conscience of our } \\
\text { nation in the long march } \\
\text { towards civil rights. They've } \\
\text { sacrificed so much for the } \\
\text { national good. Yet nearly four } \\
\text { in } 10 \text { African- } \\
\text { American children still live in } \\
\text { poverty and } 58 \text { percent, as I } \\
\text { said, of young African- } \\
\text { Americans are not working. } \\
\text { They cannot find a job. We } \\
\text { must do better as a country. I } \\
\text { refuse to believe that the } \\
\text { future must be like the past. It } \\
\text { won't be. Our future is going } \\
\text { to be a great future for } \\
\text { everyone. For everyone." }\end{array}$ & Logos. \\
\hline $26: 02$ & $\begin{array}{l}\text { And when we tell them that } \\
\text { there will be a substantial tax } \\
\text { on the cars that they make in } \\
\text { Mexico and other places, } \\
\text { number one, they're not going } \\
\text { to move in the first place, and } \\
\text { number two, if they do, our } \\
\text { country will make one heck } \\
\text { of a lot of money." }\end{array}$ & Logos. \\
\hline $30: 22$ & $\begin{array}{l}\text { "I'm not in any way, shape or } \\
\text { form an isolationist. I don't } \\
\text { believe in it, but we have } \\
\text { to make great deals for our } \\
\text { country. We're losing in our } \\
\text { whole trade negotiation with }\end{array}$ & Ethos. \\
\hline
\end{tabular}




\begin{tabular}{|l|l|l|}
\hline & $\begin{array}{l}\text { oil countries over } \$ 800 \\
\text { billion a year. That's our trade } \\
\text { deficit. Who negotiates these } \\
\text { deals? We want great trade } \\
\text { deals and we will have } \\
\text { them." }\end{array}$ & \\
\hline $37: 50$ & "I'm funding my campaign." & Ethos. \\
\hline
\end{tabular}

\section{Speech \#6- Remarks on "Obamacare"}

Valley Forge, PA

\section{1/01/2016}

\section{2,000 estimated capacity}

\begin{tabular}{|c|c|c|}
\hline Time & Remark & Rhetorical Device \\
\hline $31: 22$ & $\begin{array}{l}\text { "While he was an amazing } \\
\text { competitor, he"s an even } \\
\text { better physician. So amazing. } \\
\text { I can only hope he will play a } \\
\text { major part in my } \\
\text { administration." }\end{array}$ & Ethos. \\
\hline $34: 30$ & $\begin{array}{l}\text { "Premiums will increase by } \\
60 \% "\end{array}$ & $\begin{array}{l}\text { Very low-energy-Trump. He } \\
\text { sounds sick. }\end{array}$ \\
\hline $44: 16$ & $\begin{array}{l}\text { "The spirit of the people in } \\
\text { the inner cities is beyond the } \\
\text { spirit of anybody. And } \\
\text { it's gonna work. } \\
\text { It's gonna work. You watch. } \\
\text { Americans are tired of being } \\
\text { told to defer their dreams to } \\
\text { another day. But politicians } \\
\text { for the most part really mean } \\
\text { another decade, because that's } \\
\text { what they're talking about. } \\
\text { Enough waiting. Time is } \\
\text { now." }\end{array}$ & $\begin{array}{l}\text { Trump does not deviate from } \\
\text { teleprompter. Wraps up } \\
\text { speech very early; almost } \\
\text { earlier than intended. }\end{array}$ \\
\hline
\end{tabular}

\section{Speech \#7- Final Day Rally}

\section{Raleigh, North Carolina J.S. Dorton Arena}

11/07/2016

8,000 estimated capacity.

\begin{tabular}{|l|l|l|}
\hline Time & Remark & Rhetorical Device \\
\hline $2: 34$ & "It's time to reject the media & Pathos. Plays of fear. \\
& $\begin{array}{l}\text { and political elite that has } \\
\text { bled our country dry... They } \\
\text { rarely give you the truth. You } \\
\text { know it. And they know it. }\end{array}$ & \\
\hline
\end{tabular}




\begin{tabular}{|c|c|c|}
\hline & $\begin{array}{l}\text { That's the scary part. They } \\
\text { know it." }\end{array}$ & \\
\hline $3: 30$ & $\begin{array}{l}\text { "We're going to bring back } \\
\text { the jobs that have been stolen } \\
\text { from you. We're going to } \\
\text { bring back the wealth that has } \\
\text { been taken from our country. } \\
\text { We're going to bring back the } \\
\text { miners and the factory } \\
\text { workers and the steel } \\
\text { workers. We're going to put } \\
\text { them back to work." }\end{array}$ & Anaphora. \\
\hline $4: 20$ & $\begin{array}{l}\text { "But she lied during the } \\
\text { debate. She lied during the } \\
\text { debate. She said it's the gold } \\
\text { standard. And then she said } \\
\text { she never said it." }\end{array}$ & Repetition. \\
\hline \multirow[t]{2}{*}{$6: 02$} & $\begin{array}{l}\text { "Sadly, it's just been } \\
\text { announced that the residents } \\
\text { of North Carolina are going } \\
\text { to experience massive } \\
\text { double-digit premium hikes. } \\
\text { Ninety-five of the } 100 \text { North } \\
\text { Carolina counties will only } \\
\text { have one insurer in the } \\
\text { Obamacare exchange next } \\
\text { year. Lots of luck } \\
\text { negotiating." }\end{array}$ & Logos. \\
\hline & $\begin{array}{l}\text { "By the way, doctors, they're } \\
\text { leaving. They're quitting. I } \\
\text { have a friend who's a doctor. } \\
\text { He said that I have more } \\
\text { accountants than I have } \\
\text { nurses, it's so complicated." }\end{array}$ & Narrative. Pathos. \\
\hline
\end{tabular}




\section{Second Pass - Nonverbal Communication}

\section{Speech \#1- Presidential Campaign Announcement $6 / 15 / 2015$ \\ Trump Tower, New York, NY}

00:00- Trump descends from the top of Trump tower on an elevator with his wife by his side. He is wearing a red tie and repeatedly gives two thumbs up. Ivanka, the only other family member there, is waiting by the podium. The media is on the ground floor, while supporters are above him. It is an interesting venue layout, and ironically one Trump will never use again.

2:00- Appearance: Trump is wearing a large, long silk tie and no watches. Trump is also wearing a white shirt without collar buttons, and a navy blazer with an American flag pin on the left side. Trump is very tan, especially for June in New York. This look could have been achieved with a spray tan, and I wouldn't be surprised if he dyed his hair.

2:24- It becomes apparent that Trump wants to make a point when he uses a downward slicing motion with his right hand.

2:27- Trump makes his often-parodied right hand "ok" sign.

3:17- Trump looks up and acknowledges the crowd for the first time, thanking them for cheering. It is the only time he smiles in the speech.

4:28- Another favorite gesture of Trump's is using a gun like emblem with his right hand. He comes down on the beat of his cadence. 
4:28- Trump is using notes. This usage will change as time goes on in his later speeches.

6:40- When Trump asks a question in mockery, he hikes his left eyebrow up.

7:14- Trump finally engages his left hand. He asks a question and leaves both hands out and upward.

9:58- Trump pushes both hands together, almost swatting at the air. This signifies a rhetorical question.

16:36- Trump's hand gestures are absolutely non-stop. There is hand slashing, pointing, and speaking with his palms up. His right hand dominates each gesture.

16:55- After Trump announces he is running for president, the DJ plays "Rockin" in the Free World." Trump just stands there and bobs his head. Then, Trump points to the DJ and tells them to cut the song.

21:45- It is interesting to see that, as Trump gets more relaxed in his speech, his frequency in using his left-hand increases.

26:25-Trump, by this point, has hardly referenced his notes since the 15 -minute mark. He has become increasingly more comfortable ad-libbing. 
28:29- Whenever Trump changes a talking point, he will change gestures.

32:52- Trump points to and acknowledges his family in the corner. The camera does not pan to his family.

36:00- Trump does a parodied shoulder shrug.

41:24- Trump has a very deadpan humor delivery. He doesn't smile or laugh at his own jokes.

\section{Speech \#2 Cleveland, Ohio Rally \\ 03/12/2016 \\ Three days before Trump loses Republican primary to John Kasich (46\% to $35 \%$ ) I-X Center}

00:00- Trump is wearing a silk, solid blue tie, with a white shirt and black blazer. Almost everyone behind him is white, but the age range is quite varied. One man is wearing a "Built Trump Tough" shirt, obviously a play on Ford's motto, "Built Ford Tough." There are many signs saying, "The Silent Majority Stand with Trump." This is a reference to Nixon's silent majority. Surprisingly, there are not as many MAGA hats.

00:07- He shakes his head in disbelief at the crowd.

00:12- Trump begins his speech smiling much more than the previous one. 
00:38- Trump points directly at the media and mocks them, scrunching up his nose. People behind him start laughing.

1:10- A protestor interrupts. Trump points to the protestor and makes a joke, then does not watch security remove them. Trump shakes his head and smiles.

3:32- Trump shakes the hand of an Ohio politician, something Trump hates to do.

4:06- Trump's tone is a lot more boisterous in front of the bigger crowd. His volume is amplified. He speaks very quickly, in a drumbeat-marching band like cadence.

4:21- Trump does not stop with the hand gestures. Almost every word or phrase has an accompanying hand gesture.

5:01- Trump is much more comfortable with pausing for his clapping audience. His timing has improved.

6:32- Trump uses his right hand almost exclusively

6:40- Trump seems to man-handle his surroundings during speeches. He grips the podium almost as if it will get away from him. He leans forward into the mic, but sometimes will bounce away from it.

7:12- Trump does an imitation of Bernie Sanders, portraying him as weak and scared. 
9:53- Trump is a big user of the finger-up, pointing gesture in this speech.

13:03- Trump walks around as the crowd does a USA chant, and security escorts the protestor out.

Trump becomes more comfortable leaving the podium.

15:24- The camera pans to show the crowd. There is lots of red, and only Trump approved signs are shown.

16:14- Trump illustrates Marco Rubio's height. Rubio is 5’9.

17:20- Every time Trump refers to Rubio, he makes a hand gesture referencing his height. He does not, however, speak on his height.

19:23- Trump uses a hand-flick gesture, commonly used when dismissing an idea.

Speech \# 3- Remarks after winning Primaries in Montana, South Dakota, New Mexico, New Jersey and California.

(Nomination secured.)

$06 / 07 / 2016$

Trump National Golf Club, Westchester, New York Attendance: 500 people

00:00- Trump enters with his family. Queen's "We are the Champions" is playing. When not surrounded by people, he always lines up American flags behind him. Entire family is behind 
him, but he is flanked by Melania and Ivanka. Also, this is the first time Trump is wearing a colored tie that is not solid. He is speaking at a smaller venue, the Trump National Golf Club. 1:28- Trump has a huge smile and is laughing.

1:41- Trump uses a sweeping motion with both hands and says, "More votes than any campaign in history."

2:00- Trump uses his signature "okay" point emblem.

2:14- Trump utilizes a common facial expression, pursed lips to show his approval.

4:00- Trump uses both hands, palms facing toward the crowd, and chops up and down while saying, "Fantastic trade deals."

5:31- This is the first time Trump makes a gesture with his left hand only.

7:20- Trump does an undercut chop, the first gesture that is not the "ok" or the point.

7:41- Trump makes a wiping motion with his hands to illustrate Hillary Clinton cleaning her emails.

8:58- Trump flares his hand up and down and says, "I didn't need to do this."

9:14- Trump has a long grim smile, and bobs his head.

10:33- "We're broke," he says while his hand makes an explosion gesture.

12:30- Side note, Melania and Ivanka have been doing a great job actively listening. They are both in the frame for the entire 20 -minute speech and are engaged. They nod their heads and give other signals of engagement throughout.

13:41- Trump is interrupted by a supporter, and handles the interruption well. He acknowledges the supporter and moves on.

16:20- As Trump concludes his speech, he speaks quicker, and louder. He ends with MAGA. 


\begin{tabular}{|c|c|c|c|c|c|c|c|}
\hline \multicolumn{8}{|c|}{ Third Pass- Message Frequency } \\
\hline & Speech 1 & Speech 2 & Speech 3 & Speech 4 & Speech 5 & Speech 6 & Speech 7 \\
\hline \multicolumn{8}{|l|}{ Third Pass Themes } \\
\hline Running Time & $47 \mathrm{~min} 8 \mathrm{sec}$ & $38 \mathrm{~min} 59 \mathrm{sec}$ & $17 \mathrm{~min} 24 \mathrm{sec}$ & $1 \mathrm{hr} 15 \mathrm{~min} 3 \mathrm{sec}$ & $43 \mathrm{~min} 05 \mathrm{sec}$ & $50 \mathrm{~min} 51 \mathrm{sec}$ & $50 \mathrm{~min} 59 \mathrm{sec}$ \\
\hline Immigration/The Wall & 2 & 1 & 1 & 9 & 3 & $3 \quad 1$ & 5 \\
\hline Jobs & 4 & 3 & 3 & 6 & 10 & 3 & 4 \\
\hline Ad Hominem Attack & 5 & 5 & 1 & 2 & 6 & 0 & 8 \\
\hline Black America & 0 & 1 & 2 & 1 & 9 & 1 & 2 \\
\hline Trade & 7 & 1 & 3 & 5 & 4 & 1 & 3 \\
\hline Reagn/Nixon "Classical Conservatism" & 1 & 1 & 1 & 2 & 3 & 1 & 5 \\
\hline MAGA & 6 & 1 & 3 & 6 & 3 & 2 & 4 \\
\hline Obamacare & 3 & 0 & 0 & 1 & 2 & 5 & 3 \\
\hline
\end{tabular}

\section{Discussion}

At the podium, Trump is unlike any other politician. He is not afraid of the consequences of his words. One of the most frowned upon strategies and rhetorical fallacies in the communication studies community, the ad hominem attack, is thoroughly embraced by Trump. He is expressive, and uses so many nonverbals that an analysis on Trump's nonverbal communication reached research saturation by the third message. Trump is not afraid to be loud, boisterous, and uses a teleprompter only as a suggestion. The message candidate Trump delivered is one fed by two distinct themes: disruption-based populism and nostalgia.

\section{Disruption-based Populism: America First, the Wall, and Winning}

Every political candidate in history has added an element of populism to their speeches. However, Trump's wave of populism brought an element of disruption to the political and social systems, which had been accepted as the norm for decades. Since the end of World War II, American foreign policy was built upon the need to be a shepherd for the world. It was generally accepted that with great power in the world comes great responsibility. Republican and Democratic administrations supported this notion. However, Trump empathetically adopted an "America first" message. He used the unpopular wars in Afghanistan and Iraq, generous trade deals, and global organizations' dependency on U.S. assistance to illustrate the idea that America was being taken advantage of by the global community.

From an immigration stand-point, Trump's message again disrupted a social norm which has been accepted since the founding of this nation. Immigration has been feverishly encouraged. Themes such as Kennedy's "A nation of immigrants," Truman's "Immigration is the greatest form of flattery," and the Statue of Liberty's "Bring me your tired, your poor, your huddled masses yearning to be free," were all challenged in Trump's frequent messages about "The Wall." He quietly supported legal immigration, however, he feverishly bashed on illegal immigration, promising to strip rights afforded to illegal immigrants in this country. 
Economically, Trump's message used logos and ethos to show he could bring greater fiscal prosperity. What Trump admittedly lacked in military and political experience, he made up for by frequently bragging about his business successes. As an appeal to ethos, he mentioned his net worth five times in the seven speeches observed. Perhaps the greatest use of the President's logos was in Dimondale, Michigan where he physically pointed to a closed down Ford plant in his speech. In a speech targeting the economic suffering of African American communities, he used logos via a rhetorical question asking Black voters "After all these horrible truths, I wonder, what do you have to lose by voting for me?"

Nostalgia: Make America Great Again

A discussion of Trump's rhetoric would be remiss if it did not look at his use of American nostalgia. Perhaps most prominent is his use of the slogan "Make America Great Again." Ironically, this is not a new political rally cry. This slogan was used by the Reagan campaign in the 1980's. It is not the only recycled message from days of old. Frequently at Trump rallies, the sign "The Silent Majority Stand with Trump" was handed out. This harkens back to President Richard Nixon who used the term "Silent Majority" to describe how a majority of Americans supported the Vietnam War, but they were not the most vocal about it. Trump indirectly referenced classical conservative notions used by Ronald Reagan, Barry Goldwater, and Richard Nixon fourteen times throughout eight speeches. Trump ended every speech with the MAGA slogan, and the marketing guru funded $\$ 45$ million of his campaign off sales of the Make America Great Again hats.

\section{Audience Impact: Excite, not Pander}

Despite Trump's consistent deviation from what academia believes is the proper way to deliver and write a public address, Trump does follow one major conventional tenet of our discipline: a speech is only as effective as the audience receives it.

Trump knew his audience. Geographically, the eight speeches observed targeted key swing voters in Michigan, Ohio, Pennsylvania, North Carolina, Florida, and Nevada. Each speech highlighted slightly different themes which addressed specific voters in those states. An example comes from Trump's address in Valley Forge, PA. Pennsylvania was one of the most aggressive states to embrace the Affordable Care Act. Candidate Trump dedicated an entire speech to those in rural Pennsylvania who felt like their health needs were being dictated by Democratic legislators in Harrisburg, and it worked. Those rural Pennsylvanians showed up as $70.11 \%$ of registered voters participated in the 2016 election. The highest turnout since 1992.

Many campaigners for the Democratic party targeted young, diverse, and educated individuals. Trump defied many pundits and pollsters by believing he could rally older, white, rural voters to outnumber the new target demographic of the Democratic Party.

When analyzing Trump's audience, it becomes apparent that he uses pathos masterfully. Trump embodied what his audience craved: an angry outsider willing to fight for them. To quote from his Republican National Convention speech, he was "their voice." Trump understood and promoted his role as messenger. From his storytelling, to the conversational structure Trump used in his rallies, he connected with his audience and gave them a feeling of empowerment. He excited the Republican base in every state he went to and caused voter turnout to rise to a greater level than ever seen before. 
Normally, in a democratic-republic like the United States of America, the answer to the research question (if the President's rhetoric helped secure his presidency) lies in the hands of the people and the final outcome of a Presidential Election. However, in this case, the answer is not clear. On November 9, 2016, the popular vote overwhelmingly sided with candidate Hillary Clinton, but the electoral college elected Trump. However, from a communication perspective, Trump used central tenets such as Aristotle's proofs, unique nonverbal communication, and repetition to highlight his message. He also used ad hominem attacks and a brash delivery to shock the world into listening and his rhetoric, which was proven a major factor in securing his victory.

Perhaps what was most effective about Trump's rhetoric is not that he tried to "sway" voters, as most political candidates have done, instead he focused on exciting his voter base. Both Trump and his campaign team believed that there were enough voters out there to get him elected; they just had to give voters a performance worth going to the polls for. In the end, the Trump rallies did just that. More than the tweets or the debates, it was the Trump Rally that became the catalyst for his campaign. They were not just speeches, but performances. For many of these small, rural towns, the Trump Rally was the biggest performance to happen in years. Trump Rallies were televised and covered like no other political event during that election season. Trump knew the people wanted a show, and he gave them one. He captured his audience via humor, storytelling, anger, and hope in the span of an hour and a half production. Ultimately, Donald J. Trump's rhetoric was a key factor in allowing him to secure the presidency.

\section{Conclusion}

\section{Key takeaway for Communication Studies}

Ultimately, this research is only as useful as it can be applied to the communication studies discipline. Perhaps the biggest takeaway for the discipline from this research is distinguishing between what is appropriate communication and what is effective communication. For example, it has long been taught that the ad hominem attack was inappropriate in a public address. However, that does not mean it is not effective. Donald J. Trump's campaign was clear evidence that when an audience has a common enemy (i.e. Hillary Clinton) the use of the ad hominem attack is effective in connecting with them.

\section{Further research}

This study was delimited for several reasons, one being that the sheer amount of data points was enormous. Future research should consider factors such as Trump's Twitter and his debate performances. Additionally, while seven speeches returned a vast amount of data, I would suggest a greater sample and variety of speeches to further add to this research.

Furthermore, Donald Trump's performance in the 2016 rallies and speeches is only one factor in how he secured the presidency. Further analysis should be conducted on Democratic presidential candidate Hillary Clinton's rhetoric. A comparative study using this research could help paint a more thorough and balanced picture of the rhetoric of the 2016 election. 


\section{References}

Kayam, O. (2016). Donald Trump's Rhetoric. Language and Dialogue, 8(2). https://doi.org/10.1075/ 1d.00012.kay

Knapp, M. L., Hall J. A., \& Horgan, T. G. (2014). Nonverbal Communication in Human Interaction (8th ed.). Boston, MA: Wadsworth.

Lundberg, C., \& William, K. (2008). The Essential Guide to Rhetoric. Boston, MA: Bedford/St. Martin's. McIver, M., \& Trump, D. J. (2004). How to Get Rich. New York, NY: Random House.

Milestones in the History of U.S. Foreign Relations. (2010). Retrieved April 26, 2020, from https: $/ /$ history. state.gov/milestones/1993-2000

O'Keefe, D. (1990). Persuasion: Theory and Research (Vol. 2). Newbury Park, CA: Sage Publications. https://doi.org/10.1177/002194369202900107

Remarks on Obamacare. (2016, November). Remarks on Obamacare. Valley Forge. Retrieved from https://www.c-span.org/video/?417802-1/republican-ticket-pushes-affordable-care-act-repeal-promises-alternative

Trump, D. J. (2015). Crippled America. New York, NY: Threshold Editions.

Trump, D. J. (2015, June). Campaign Announcement Speech. Campaign Announcement Speech. New York City. Retrieved from https://www.youtube.com/watch?v=apjNfkysjbM

Trump, D. J. (2016, June). Remarks after Winning Primaries in Montana, South Dakota, New Mexico, New Jersey and California. Remarks after Winning Primaries in Montana, South Dakota, New Mexico, New Jersey and California. New York City. Retrieved from https://www.c-span.org/video/?410729-1/donald-trump-delivers-primary-night-remarks

Trump, D. J. (2016, July). Republican National Convention. Republican National Convention. Cleveland. Retrieved from https://www.c-span.org/video/?c4612805/donald-trump-addresses-republican-national-convention

Trump, D. J. (2016, August). Remarks at the Summit Sports and Ice Complex. Remarks at the Summit Sports and Ice Complex. Dimondale. Retrieved from https://www.youtube.com/watch? $=$ RnUk a3QomE

Trump, D. J. (2016, March). Campaign Rally. Campaign Rally. Cleveland. Retrieved from https://www.c-span.org/video/?417332-1/republican-ticket-campaigns-cleveland-ohio

Trump, D. J. (2016, November). Remarks at J.S Dorton Arena. Remarks at J.S Dorton Arena. Raleigh. Retrieved from https://www.c-span.org/video/?418210-1/donald-trump-campaigns-raleigh-north-carolina 
Voting \& Election Statistics. (2017, January 1). Retrieved April 2, 2020, from https://www.dos.pa.gov/ VotingElections/OtherServicesEvents/VotingElectionStatistics/Pages/VotingElectionStatistics.aspx

Whitney, G. (2004). Ronald Reagan and the Conservative Movement. Grand Valley State University Department of Historical Studies. Retrieved from https://scholarworks.gvsu.edu/cgi/viewcontent. cgi?article $=1093 \&$ context $=$ ask_gleaves 